\title{
A DÉL-DUNÁNTÚL KÖZÉPFOKÚ VONZÁSKÖRZETEINEK TERÜLETI RENDJE (Egy felmérés eredményei és tanulságai a vonzáskörzet-kutatások szempontjából)
}

(The Territorial Order of the Medium-Level Catchment Areas of South Transdanubia)

\section{HAJDÚ ZOLTÁN}

\section{Bevezetés}

A Dél-Dunántúl (Baranya, Somogy, Tolna, Zala megye) $18009 \mathrm{~km}^{2}$-es területével az ország összterületének 19,4\% -át, az 1,3 millió fốt némileg meghaladó lakosságszámával az ország lakosságának 12,6\%-át teszi ki. A 74 fő/ $\mathrm{km}^{2}$-es népsũrũségével messze elmarad az országos átlagtól $\left(111 \mathrm{fô} / \mathrm{km}^{2}\right)$. A térség városodása és városiasodása a Budapest nélkül számított vidéki átlag körül van, egyes vonatkozásokban meghaladva, más tekintetben alatta maradva annak.

A vonzáskörzet-kutatások módszerei között régóta jelen van a településen élôk (a települések vezetõi) véleménynyilvánítására alapozott vonzáskörzeti kapcsolatfeltárás. (1828-ban már ezzel a megkérdezéses módszerrel mérték fel a piaci vonzáskörzeteket). Minden ilyen felmérésben jelen van egyfajta ,,tömeges szubjektív elem”, de a lényegét tekintve a módszer megbízható kiinduló pontokat nyújt egy térség belsô kapcsolatrendszerének feltárásához.

\section{A Dél-Dunántúl településhálózatának jellemzố vonásai}

Magyarország történetileg kialakult térszerkezeti és településhálózati alapjellemzõje, hogy ,,fóvárostúlsúlyos". Budapest az ország lakossága mintegy $20 \%$-ának ad otthont, s ennél általában hangsúlyosabb a más tekintetben elfoglalt pozíciója. A gazdaság, a kultúra, a döntési kompetenciák jelentôs részben a fôvároshoz kötöttek.

Minden közlekedési és térszerkezeti nagytérségi erõvonal a fôváros felé, vagy a fôvároson keresztül épült ki. A fôváros és az ország nagytérségei között alakultak ki a legszorosabb kapcsolatok. A fôváros önmaga köré integrálja a nagytérségeket, egybeszer- 
vezi az országot, s ezen túl a centrális közlekedési hálózaton keresztül mintegy ,,ellenôrzi"' az ország nagytérségei közötti kapcsolatokat.

A Dél-Dunántúl meghatározó térszerkezeti vonalai is a fỗváros irányába rendezôdnek. Az ország makrotérségi struktúrájában jelentôséggel bír a Letenye-NagykanizsaBalaton-Budapest, valamint a Barcs-Pécs-Szekszárd-Paks-Budapest térszerkezeti vonal. A térségen belül elemeiben egyre inkább megjelenik egy Zalaegerszeg - Nagykanizsa-Kaposvár-Pécs-Szekszárd belsõ erôvonal, illetve a fejlôdési pontokat összekapcsoló egyfajta - egyes szakaszaiban ma még inkább csak képzeletbeli - tengely.

A belsõ térkapcsolatok intenzitását tekintve a Dél-Dunántúl elmarad a Budapest-környék és Észak-Dunántúl mögött, de egyértelmûen megelôzi az Alföldet. Térszervezôdését tekintve a Dél-Dunántúl nem zárt körzet, s a ,, nem hivatalos körzetközpont" Pécs - nem képes a térség térszerkezeti kapcsolatait koncentrálni.

Az egyes megyék belsõ térkapcsolatszerkezete erôsen eltérõ, amelynek részben az az oka, hogy teljesen más a megye-megyeszékhely közötti demográfiai és gazdasági potenciálmegoszlás.

Baranya Pécsre koncentráló térszerkezetet mutat. A megye és a város összlakosságának mintegy $40 \%$-a él a megyeszékhelyen. Ez azt jelenti, hogy Pécs kétszer akkora túlsúllyal van jelen Baranya életében, mint Budapest az országéban.

Somogy megyében Kaposvár , Budapest súlyú”, szerepet játszik, a lakosság mintegy 20\%-a él a megyeszékhelyen. A Balaton-part városai rendkívül sajátos térszerkezetformáló szereppel birnak. A megyéhez tartozó, szinte megszakítás nélkül beépített partszakasz különösen nyáron alakít ki sajátos térkapcsolatokat.

Tolna megyében Szekszárd nem képes a megyén belüli térpályákat monopolizálni. A megyeszékhely a térség összlakosságának $15 \%$-át mondhatja lakójának. A megye belsõ térszerkezete és erỗvonalai többközpontúak (Szekszárd, Bonyhád, Dombóvár, Paks, Tamási).

Zala megye Zalaegerszeg és Nagykanizsa központtal kétosztatú, de egyre inkább kialakul Hévíz-Keszthely révén a megye háromosztatúsága. Zalaegerszeg - a lakosságból való részarányát nézve - Budapest súlyúnak tekinthetố megyén belül, de más vonatkozásokban a jelentôsége lényegesen kisebb.

A településhálózat országos rendszerét tekintve a Dél-Dunántúl országos specifikuma mindenekelốtt a magas településsũrüségben (a $100 \mathrm{~km}^{2}$-re jutó települések száma a DélDunántúlon 5, az országos átlag 3,3), aprófalvas jellegében (az ország 1860 ezer fố alatti településéból 684 a Dél-Dunántúlon van; a községek átlagos lélekszáma az országban 1340 fó körül alakul, míg a Dél-Dunántúlon ez az érték 800 fổ alatt marad) ragadható meg.

A Dél-Dunántúl településállományának $48 \%$-át teszik ki a 499 fô alatti települések. Különösen magas ezek aránya Baranya megyében (67,8\%). Az. 500-999 fố közötti települések aránya $23,7 \%$, így az ezer fố alatti települések adjảk a térség településállományának több mint $71 \%$-át. Ezzel szemben a 499 fố alatti településekben 
él a régió lakosságának 9,2\%-a, a magasabb kategóriában pedig 11,5\%-a, így az ezer fô alatti lélekszámú községekben összesen a régió népességének 20,7\%-a lakik.

Az 1000-1999 lakossal rendelkezõ települések száma mintegy 130. Ezekben a községekben az alapkérdés az, hogy meg tudnak-e kapaszkodni ebben a kategóriában, vagy lefelé csúsznak.

A nagyobb lélekszámú (2000-4999) települések (56) közül már több várossá alakult, $s$ a községek között is több olyan van, melyek megfelelô belsô erôforrásokkal rendelkeznek ahhoz, hogy teljeskörũen kiépüljön infrastruktúrájuk. (A nagyságrendi csoport funkcionálisan nem egységes. A volt járási székhelyek pl. Gyönk, Pacsa, Sásd, Villány jelentôs központi funkciómaradványokkal rendelkeznek, míg mások (pl. Bóly, Beremend, Nagybajom, Kadarkút, Hôgyész, Pincehely, Simontornya, Murakeresztúr, Zalalövô) változatos funkciószerkezettel bírnak.

Az 5000-9999 lakossal rendelkezô települések (9) közül mindössze Bátaszék és Szentlốrinc nem városi jogállású település. Az ebben a nagyságrendi kategóriában levô települések funkcionális értelemben kisvárosnak tekinthetốk, jelentốs térszervezési hagyományokkal rendelkeznek.

A 10 000-49 999 lakossal rendelkezó városok (15) között Szekszárd megyeszékhelyként van jelen, Komló a gazdasági és települési átstrukturálódás kezdetén álló hagyományos iparváros, Keszthely, Siófok országos, sốt nemzetközileg is elismert üdülốváros, a többiek többfunkciós települések.

A három 50 ezer fốn felüli város (Kaposvár, Zalaegerszeg, Nagykanizsa) közül az elsô kettô megyeszékhely. Ez a három város már rendszerjelleggel kiépült fejlett infrastruktúrával rendelkezik, a munkaerố képzettségi szintje regionális és országos tekintetben is jó. A három város mindenekelốtt a külföldi tôke megszerzése tekintetében versenytársa egymásnak.

A nagyságrend másik ,végletét" a több mint 170 ezres lélekszámú Pécs képezi. A város a dél-dunántúli régió virtuális központja, néhány ágazatban az egész régióra kiterjedố ,,területi illetékességgel rendelkezik”. A város nem képes a régión belüli kapcsolatokat teljeskörüen integrálni.

\section{A Dél-Dunántúl középfokú vonzáskörzet-szisztémája a községi vezetôk véleménye alapján}

1993. decemberében az MTA RKK Dunántúli Tudományos Intézete községi kérdôívvel kívánta felmérni a négy megye belsô struktúráinak állapotát. A térség minden községi önkormányzata (akkor 876) megkapta a kérdốívet, s 378 (43,2\%) kitöItött kérdôív (Baranya 43,7\%, Somogy 44,7\%, Tolna 49,5\%, Zala 38,4\%) érkezett vissza. A visszaérkezés aránya némileg eltérô, $\mathrm{s}$ az egyes megyéken belül is sajátos (1. ábra), így a teljes körũ, s minden igényt kielégítố elemzéshez kevés, de elegendõ a problémák és sajá- 


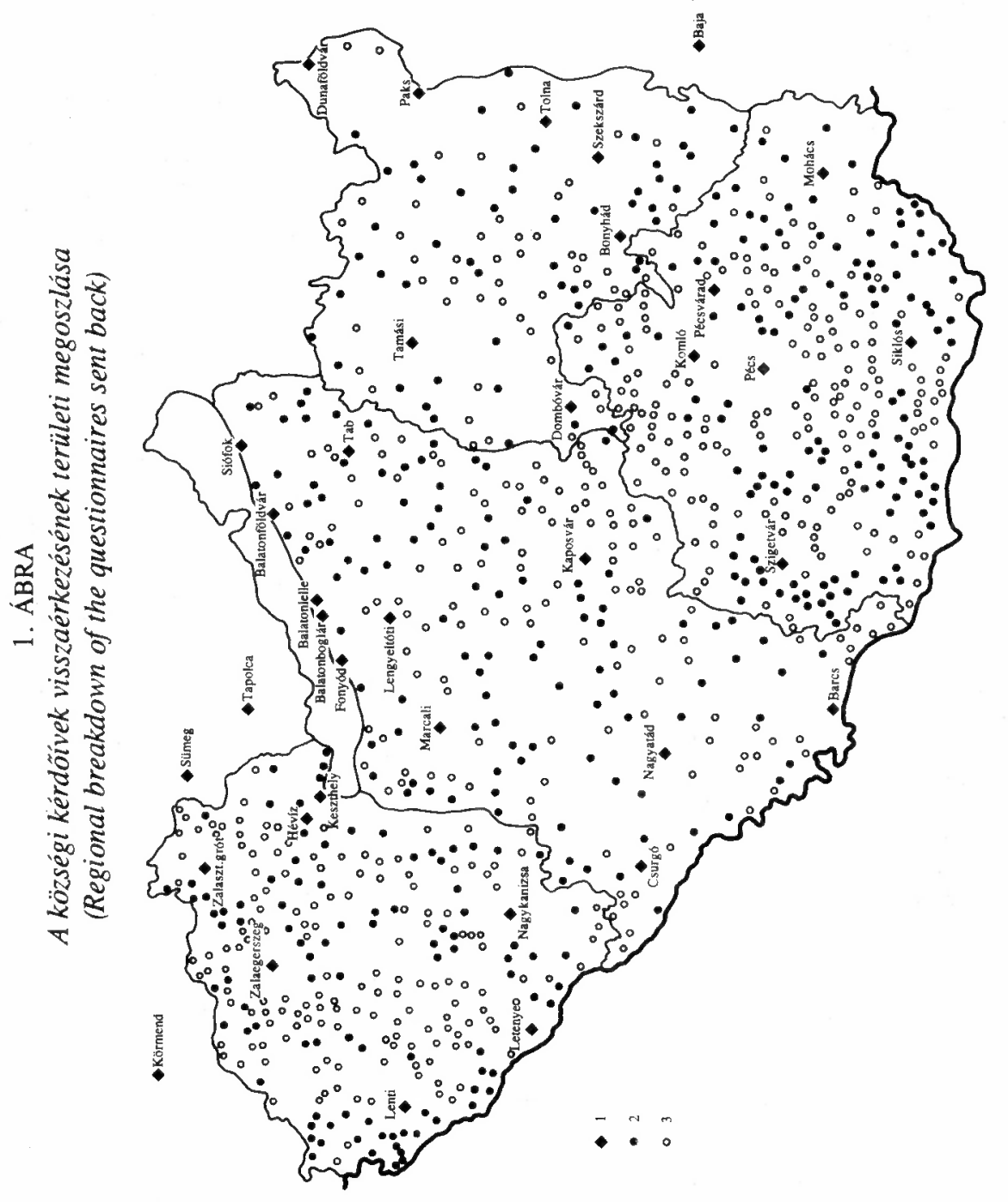


tosságok megfogalmazásához. (Annak is van jelzésértéke, hogy mely egybefüggố területekrõl nem érkezett vissza kérdốv. Elsôsorban a megye- és vonzáskörzeti határokon fekvố települések vezetése ,óvakodott" véleményt nyilvánítani).

A középfokú vonzáskörzetek területi rendje ,,perforált", de a község-város (egyes tekintetekben községközi) kapcsolatok szokszínũsége, nagyszámú község esetében osztottsága, jól nyomon követhetô.

\section{A városi igazgátási vonzáskörzetek}

Az önkormányzati közigazgatás vonatkozásában az 1990-es reform új struktúrát teremtett, melynek keretében megszuñ az önkormányzatok közötti hierarchikus viszony. A hierarchikus viszony megszüntetésével egyidőben az önkormányzati törvény lehetõséget adott az önkormányzatok önkéntes társulására.

Az állami szakigazgatásban, s egyéb közfunkciók tekintetében ma is létezik egy igazgatási kapcsolatháló, illetékességi területrendszer. A községek egy része különbözõ központokhoz tartozik az ágazati illetékességi területfelosztásokban. (Ha úgy tetszik a korábbi járási szint és területfelosztás ,,rejtetten él" tovább.)

Az igazgatási vonzáskörzetek (2. ábra) megítélése magában foglalja az önkormányzati társulások és a különbözõ ágazati területfelosztások általánosítását. A városok kirajzolódó igazgatási vonzáskörzetei néhány kivételtôl eltekintve megyehatárosak. Az igazgatási vonzáskörzetek lényegében visszatükrözik a korábbi járási struktúrát, igaz, hogy az ,, utolsó járási székhellyel" egybevetve több esetben némi eltérést mutatnak, elsôdlegesen az 1984-es városkörnyéki konstrukció módosító hatásai miatt. A városok közül Balatonföldvár, Dunaföldvár, Hévíz, Lengyeltóti nem jelent meg igazgatási vonzáskörzeti központként.

\section{Középfokú oktatási vonzáskörzetek}

Az oktatási településközi kapcsolatok - éppen az aprófalvas jelleg következtében az általános iskolai szinttôl kezdve széleskörũen megjelennek. Az iskolakötelezettség kiterjesztése a jövổben új településközi oktatási kapcsolatokat hoz majd létre.

A középfokú iskolák képzési specifikuma eltérô, így a településközi vonzáskapcsolatok tekintetében nem volt ritka, hogy egy-egy község két-három város középfokú iskolai vonzását is megjelölte.

A városok középfokú oktatási vonzáskörzeteit (3. ábra) vizsgálva mindenekelôtt azt kell megjegyeznünk, hogy a megyeszékhelyek vonzása erõsen kiterjedt, s az oktatási kapcsolatok sok esetben ,,átnyúlnak" a kisvárosok domináns vonzáskörzetei felett. Ebbôl a szempontból különös figyelmet érdemel Kaposvár, Pécs, Zalaegerszeg. A megyehatárokon átnyúló vonzás Nagykanizsa térségében a legnyilvánvalóbb, de eseti 


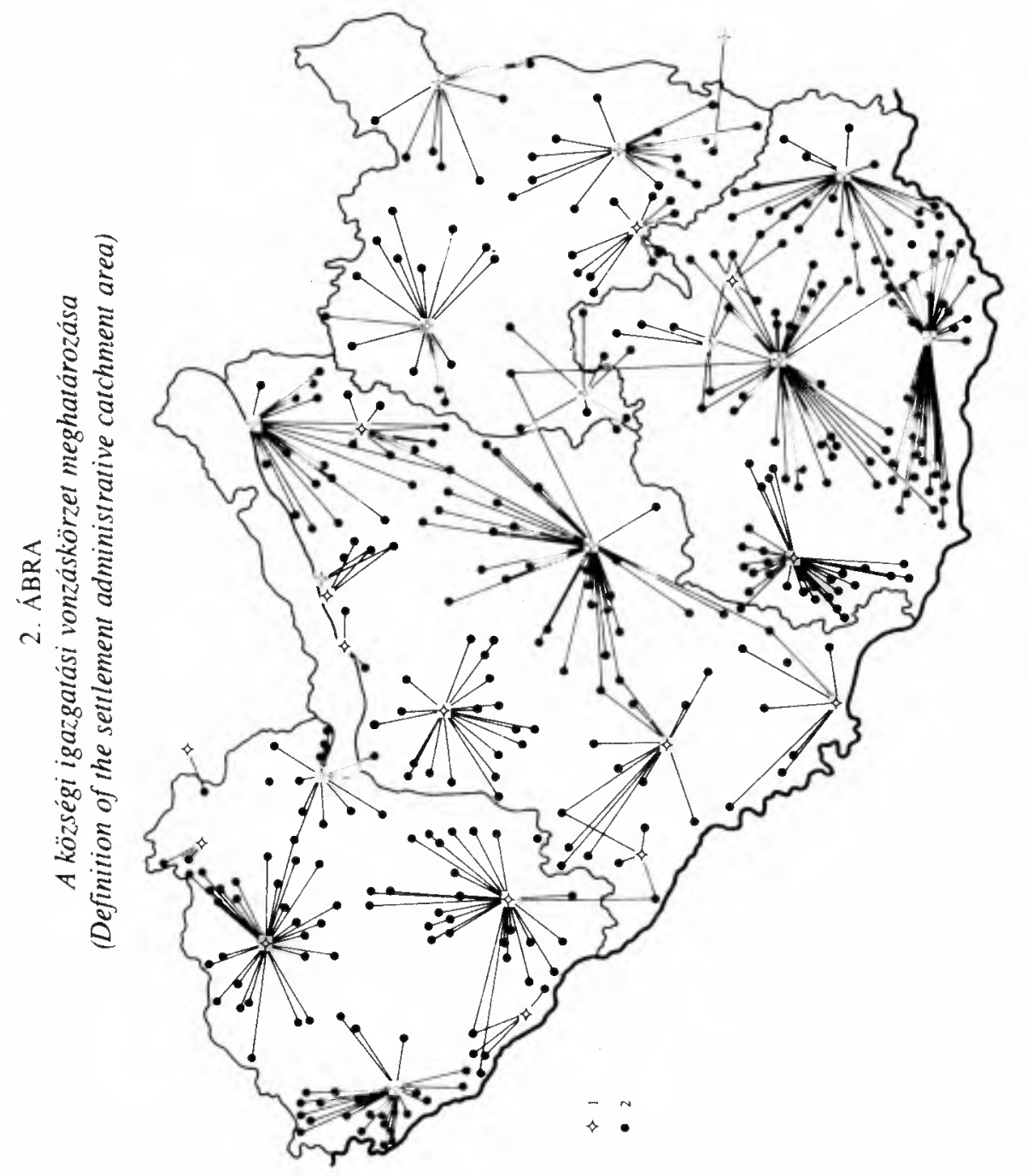




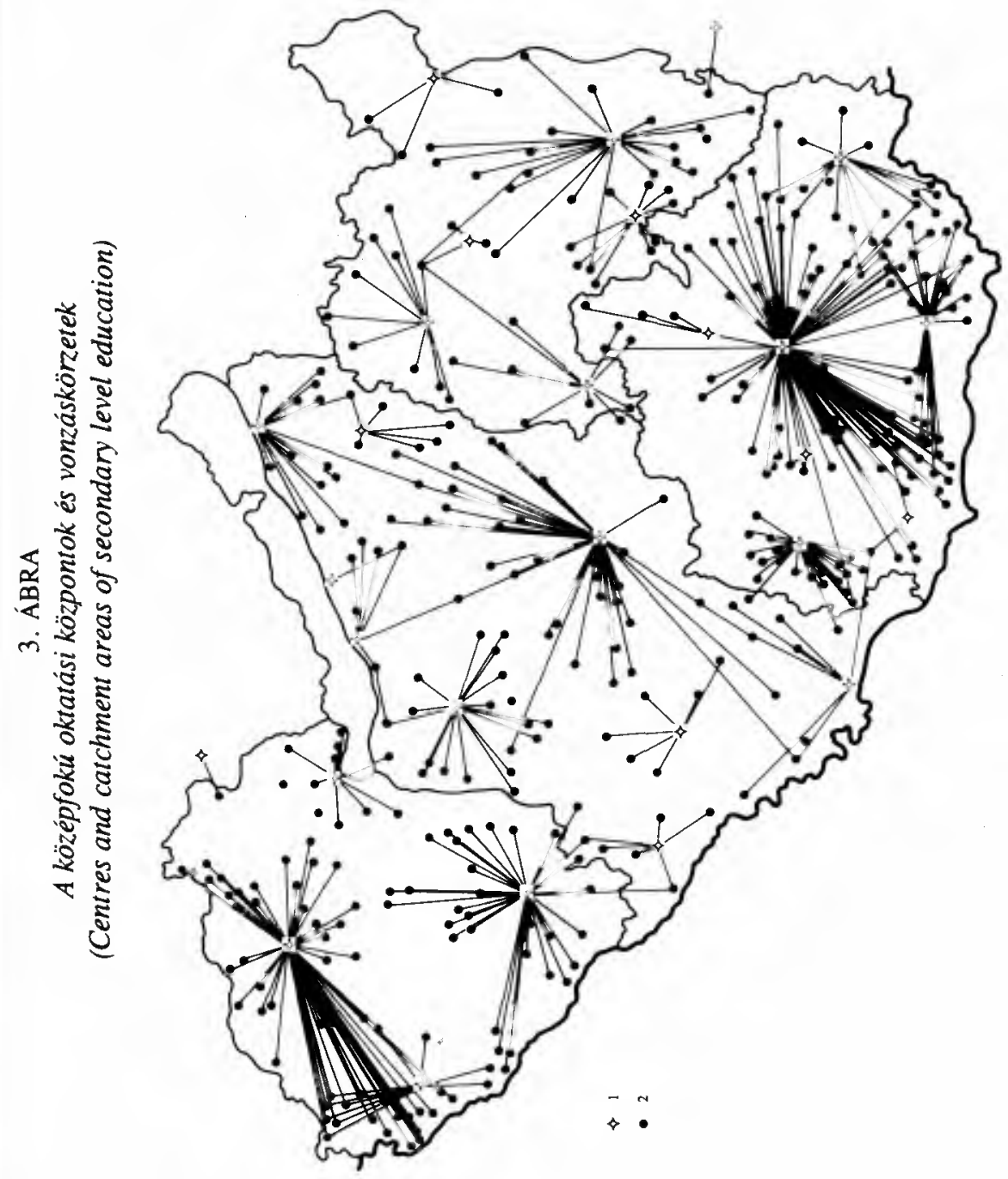


jelleggel másutt is érvényesül. A kettôs, illetve hármas vonzódás a vonzáskörzethatáron fekvõ települések esetében jelenik meg nagyobb számban. A nem városi jogállású középfokú oktatási központok közül Gyönk, Szentlórinc és Sellye került vonzásközpontként megfogalmazásra.

\section{A kereskedelmi térkapcsolatok és vonzáskörzetek}

A kereskedelmi központok hierarchiája tagoltabb, mint a többi vizsgált ágazaté. Ezzel magyarázható, hogy a vonzásközpontként megjelölt települések száma a kereskedelem tekintetében a legmagasabb (4. ábra).

Mikrotérségi kereskedelmi központként határozható meg a vizsgált települési körben: Zalában Letenye; Somogyban Balatonmáriafürdô, Lengyeltóti, Fonyód, Balatonboglár, Balatonlelle, Csurgó, Balatonföldvár, Kadarkút, Tab; Tolnában Simontornya, Gyönk, Nagydorog, Tolna, Bátaszék; Baranyában Pécsvárad, Bóly, Villány, Sellye, Szentlôrinc, Vajszló.

Kistérségi kereskedelmi vonzáskörzettel rendelkezik: Baranyában Szigetvár, Komló, Siklós, Mohács; Somogyban Barcs, Nagyatád, Marcali, Siófok; Tolnában Bonyhád, Dombóvár, Tamási, Szekszárd, Paks; Zalában Keszthely és Lenti.

Mezotérségi, s más városok kereskedelmi vonzáskörzetébe is ,,benyúló" vonzással, illetve kereskedelmi vonzáskörzettel rendelkezik Kaposvár, Pécs, Zalaegerszeg, valamint a nem megyeszékhely Nagykanizsa.

A kereskedelmi vonzáskörzetek minden más területi kapcsolatnál nagyobb mértékben, $\mathrm{s}$ a mindennapi életben gyakrabban lépik át a megyehatárokat. Különösen szembetũnô Baja ,,régióközi" kereskedelmi vonzó hatása.

\section{A pénzügyi kapcsolatok}

A pénzügyi településközi kapcsolatok megítélése valószínũleg a felmérés legbizonytalanabb eredményét jelenti, a pénzügyek bizalmas jellegénél fogva. Az önkormányzat folyószámlájának vezetési helye nyilvános, így annak megjelölése nem okozott gondot. A gazdasági szervezetek, vállalkozók, s különösen a lakosság pénzügyi településközi kapcsolatainak megítélése sok véletlenszerũ és esetleges elemet hordozott.

A pénzügyi térkapcsolatok (5. ábra) viszonylag decentralizált képet mutatnak. A városok és történeti járási székhelyek mellett új települések is megjelennek központként. Ez azzal magyarázható, hogy jó néhány községi takarékszövetkezet meglehetôsen széles kapcsolatrendszerrel rendelkezik. A kistérségi pénzügyi kapcsolatok erôteljesen felértékelôdhetnek a magángazdaság, különösen a mezógazdaság új feltételei és lehetôségei között. A településközi pénzügyi kapcsolatok megerôsíthetik a kisközpontok településhálózati pozícióit. 


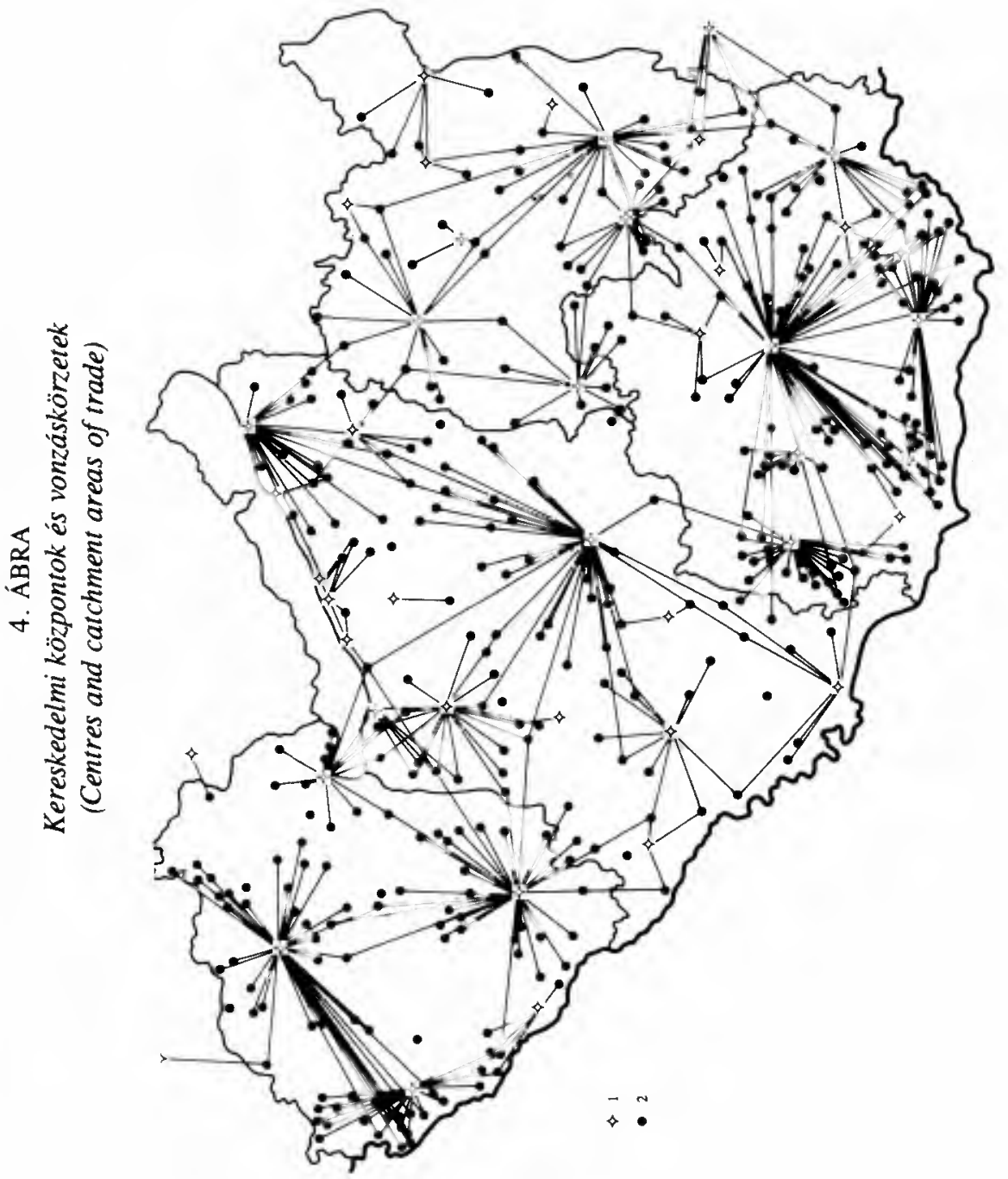




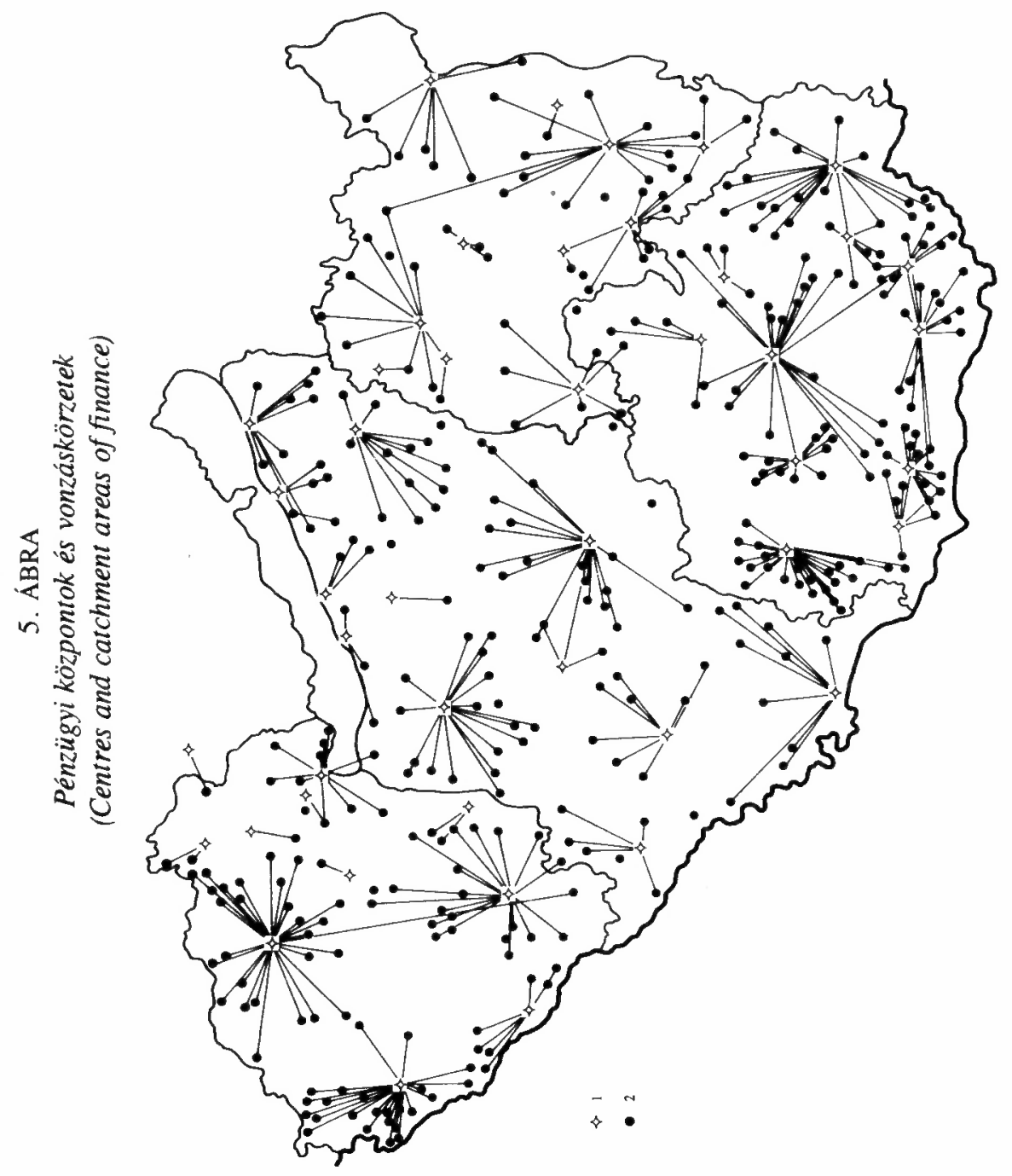

व) 


\section{A szolgáltatási jellegũ településközi kapcsolatok}

A szolgáltatási településközi kapcsolatok (6. ábra) a pénzügyiekhez hasonlóan viszonylag decentralizáltak, de lényegüket tekintve elsõdlegesen városcentrikusak, s azon belül is kitüntetett szerepük van a megyeszékhelyeknek. Néhány, a környezetében nagyobb lélekszámú és fejlettebb település (pl. Böhönye, Iregszemcse, Pincehely) elôször jelenik meg a településközi kapcsolatokban vonzásközpontként.

\section{Egészségügyi vonzáskörzetek}

Az egészségügyi térkapcsolatok az 1990-es évek reformjának következtében alakultak át adminisztratív úton szabályozott kapcsolatokból lényegüket tekintve nyitott kapcsolatokká. A szabad orvos- és kórházválasztás jó néhány település lakossága számára tényleges választási lehetôséget kínál, viszont a községek számottevõ hányada esetében formálisnak tekinthetổ a ,,jog", hiszen a legközelebbi orvos, illetve kórház elérése is jelentôs idổbe és költségbe kerül.

A középszintũ egészségügyi térkapcsolatok tekilltetében két típusú térszervezôdésrõl kell beszélnünk: a kórházzal rendelkezô települések; a csak rendelőintézettel bíró települések körül formálódó vonzáskörzetek. Teljes értékũ középfokú egészségügyi ellátásról és vonzáskörzetekrôl csak a kórházzal is rendelkezõ körzetek esetében lehet szó.

A kórházzal (is) rendelkezõ települések ellátó funkciója, különösen annak minôsége és diverzifikáltsága között is lényeges különbségek vannak. Baranya megyében Komló, Mohács, Pécs, Siklós, Szigetvár; Somogyban Kaposvár, Marcali, Nagyatád, Siófok; Tolnában Bonyhád, Dombóvár, Pincehely, Szekszárd; Zalában Keszthely, Nagykanizsa, Zalaegerszeg középfokú egészségügyi vonzáskörzete tekinthetô teljes értékũnek. (Tolna megyében sajátos struktúra jött létre: Pincehelyen kórház, Tamásiban rendelôintézet mũködik, így a két település együtt képez egy teljes értékũ középfokú egészségügyi központot).

A csak rendelőintézettel rendelkezố egészségügyi központok nem nyújtanak teljes értékủ középfokú egészségügyi ellátást. Ugyanakkor nõ e központok súlya a betegforgalom nagyságrendjében.

A középfokú egészségügyi vonzáskörzetek (7. ábra) a vártnál kevesebb átfedést mutatnak. A vonzáskörzetek csaknem ,,tiszta megjelenésủek", ami nem fejezi ki a központok minőségi különbségeinek vonzó hatását. Viszonylag kevés a megyehatárt átlépõ kapcsolat is. 


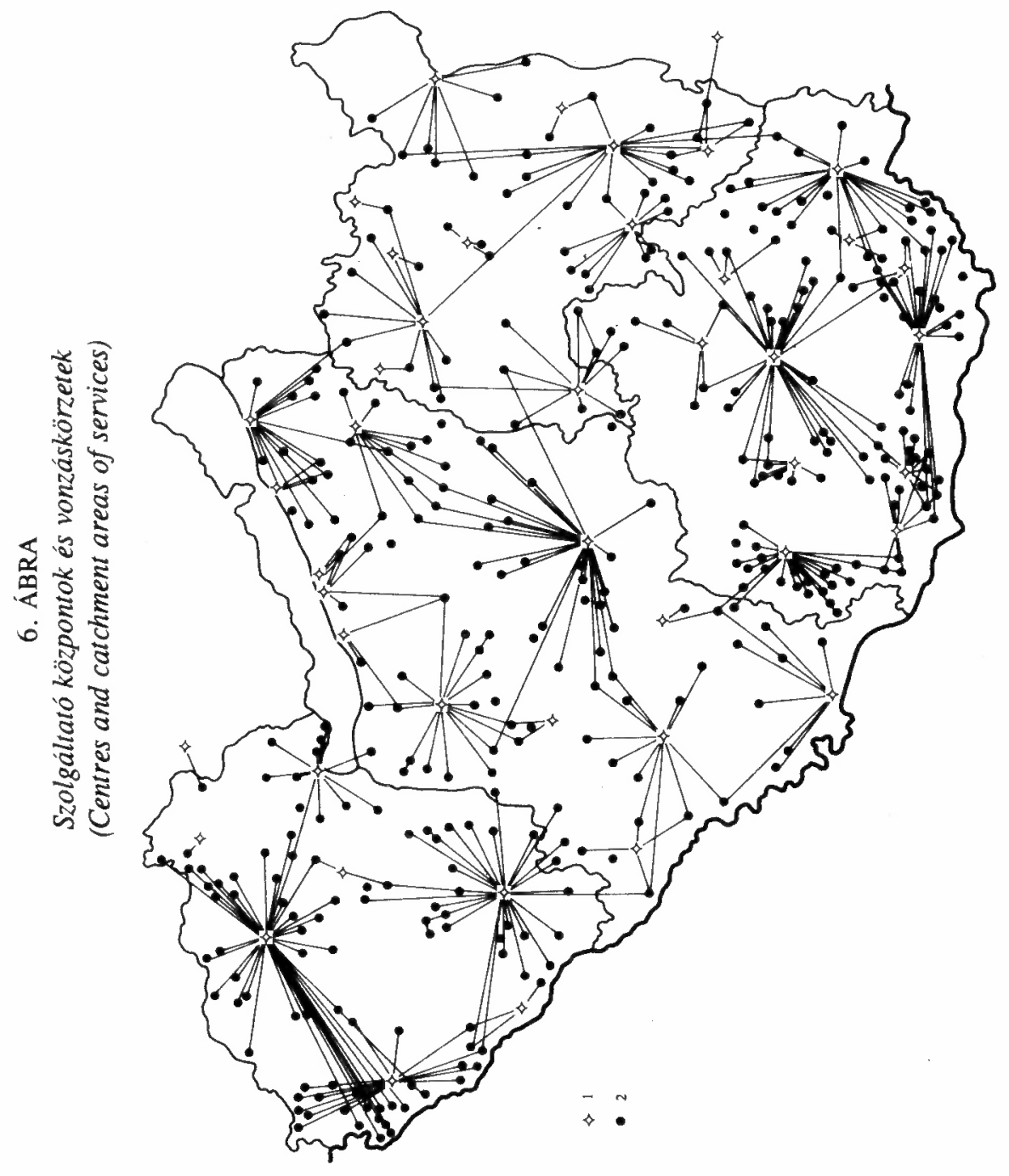




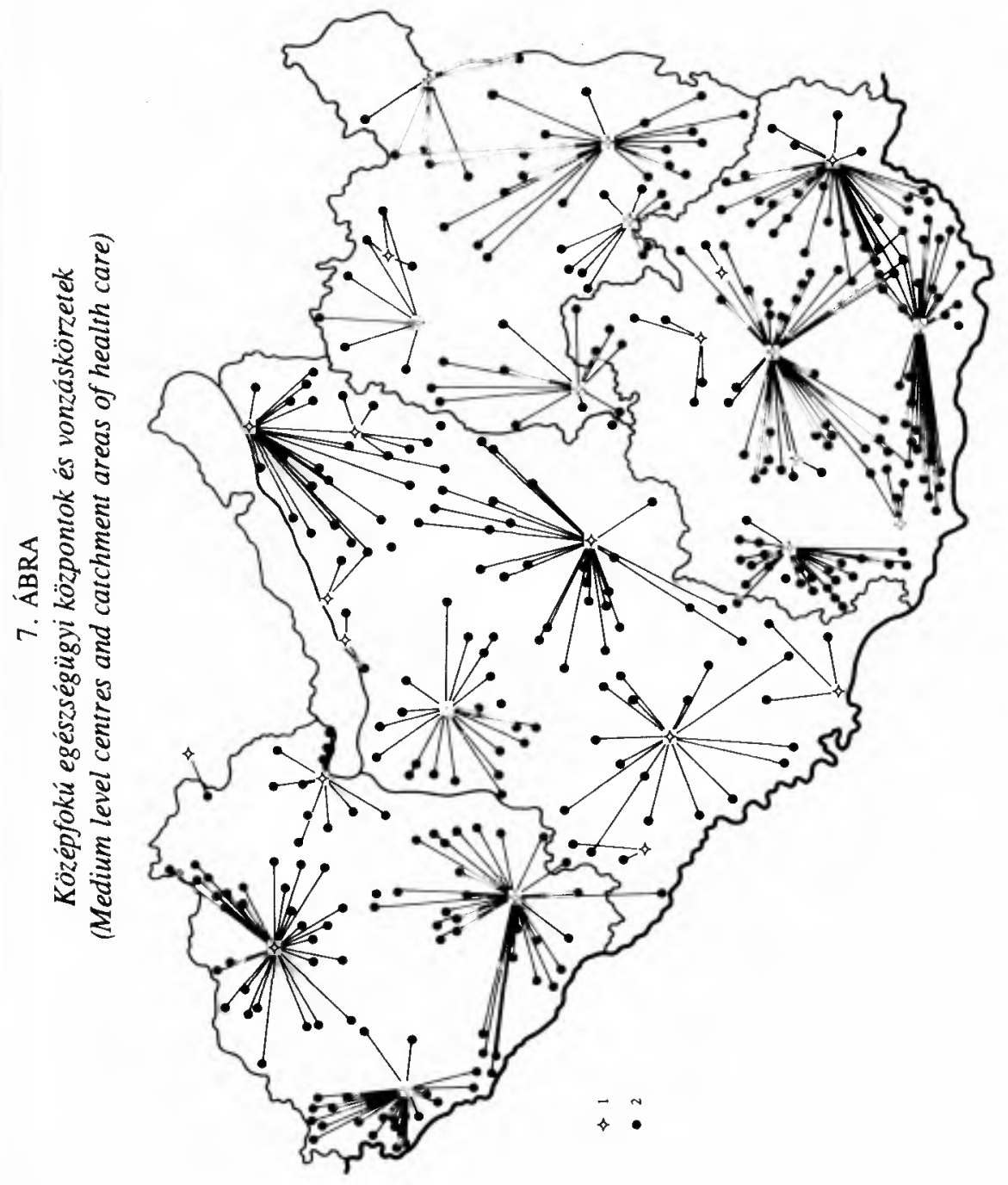




\section{Termelési térkapcsolatok}

A mezõgazdasági termelési, szervezeti, ellátási kapcsolatok csak részben ragadhatóak meg vonzáskörzeti problematikaként. A kérdôívben ezért ,,érdekeltség" néven jelöltük a kapcsolatok jellegét. A mezôgazdasági településközi kapcsolatok a kárpótlás és privatizáció következtében jelentôsen átalakultak az 1990-es évek során. A megfogalmazott települési ,,érdekeltségek" bonyolult településközi rendszert mutatnak, de válaszadóink jelentôs számban nem tudták, vagy nem akarták megfogalmazni álláspontjukat .

Az ipar vonatkozásában az ingázási településközi kapcsolatokat tekintjük egyfajta vonzáskörzet-jelzô struktúrának (8. ábra). Az ingázó központok elsôdlegesen a városok, de néhány sajátos ipari község is jelentôs térszervezõ hatást gyakorol e tekintetben. Ebbốl a szempontból nagysága miatt Beremend emelhetô ki. A megyehatárokat Nagykanizsa térségében lépik át leginkább az ingázási kapcsolatok. , Régióközi" vonzást jelent Baja, Sümeg, Tapolca, valamint Somogy megye északkeleti és Tolna megye északnyugati részén Budapest, illetve Székesfehérvár.

\section{A középfokú vonzáskörzeti térkapcsolatok összegzése}

Válaszadóink többsége (Mely település/ek/ középfokú vonzáskörzetébe sorolja leginkább a községet?) a középfokú kapcsolatok összegzését tekintve, a részválaszok feldolgozása függvényében is, jól szintetizálta a településközi kapcsolatok ,átlagát”, és besorolta községét valamely település középfokú vonzáskörzetébe (9. ábra).

A középfokú körzetek elsôsorban városközpontúak, a középfokú vonzáskörzetközpontok között megjelölt mikroközpontok elsôdlegesen értelmezési problémát hordoznak.

A lehatárolt középfokú vonzáskörzetek többségükben nem képeznek homogén teret, mindenekelôtt a megyeszékhelyek vonzása perforálja a kisvárosok vonzáskörzetét. A vonzáskörzetek több esetben átlépik a megyehatárt.

\section{A községek jövôbeni együttmũködési hajlandósága, illetve annak , , céltelepülései"}

A városokkal kialakítandó kapcsolatokban való érdekeltség és a jövốbeli együttmũködésre való hajlandóság tekintetében elég sok közremüködőnk, ,nem vállalta a besorolás felelổsségét”. Ennek ellenére izgalmas az ,,együttmüködési céltelepülések" áttekintése, s néhány település orientációjának elemzése (10. ábra).

Az együttmúködési ,,céltelepülések" elsôsorban a városok, de jó néhány esetben direkt módon megfogalmazott fenntartások jelentek meg elsõsorban egy-egy nagyvárossal szemben .

A régió, megye- és vonzáskörzeti határon fekvô települések esetleg több várossal is szívesen alakítanának ki komplex együttmüködést. 


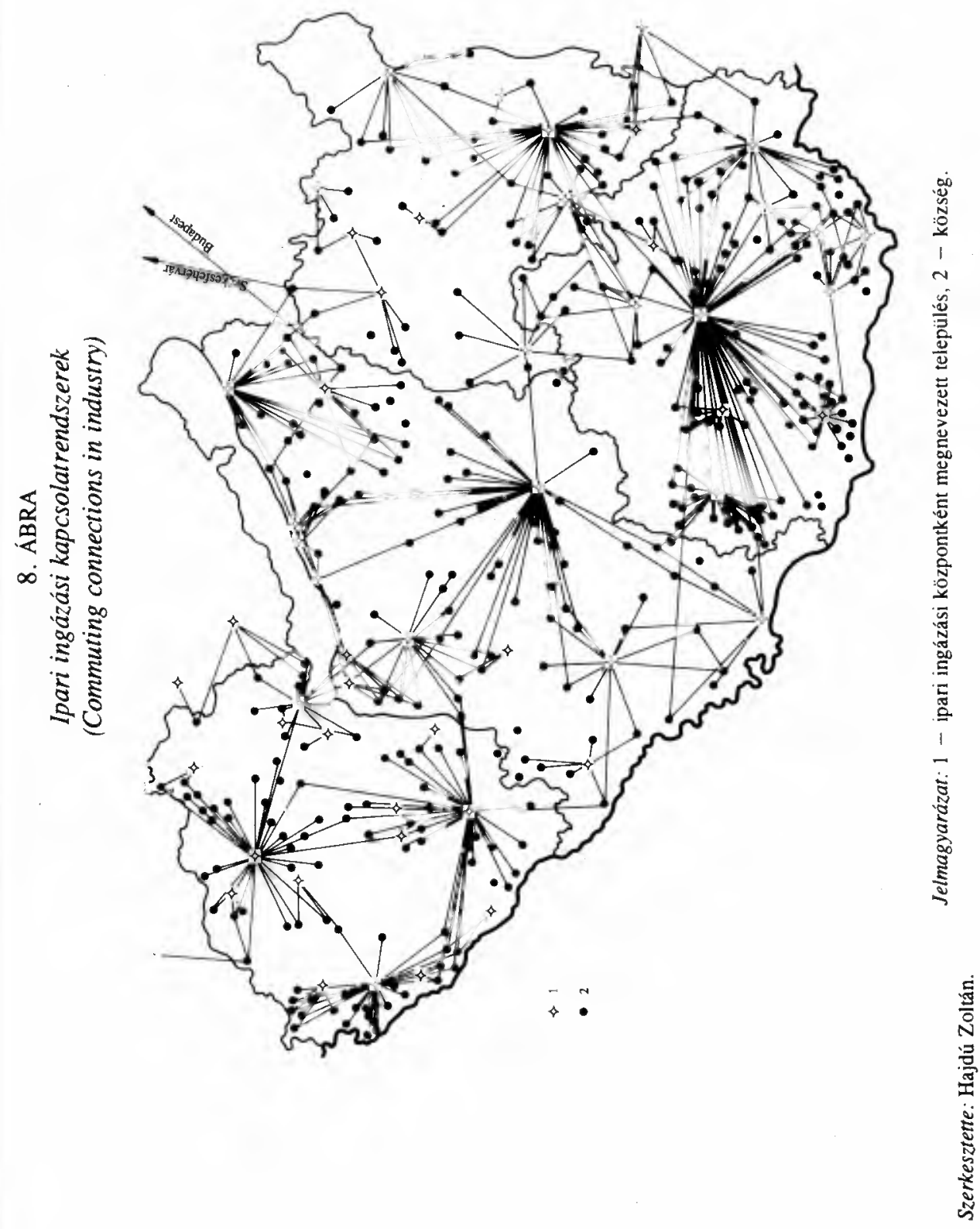




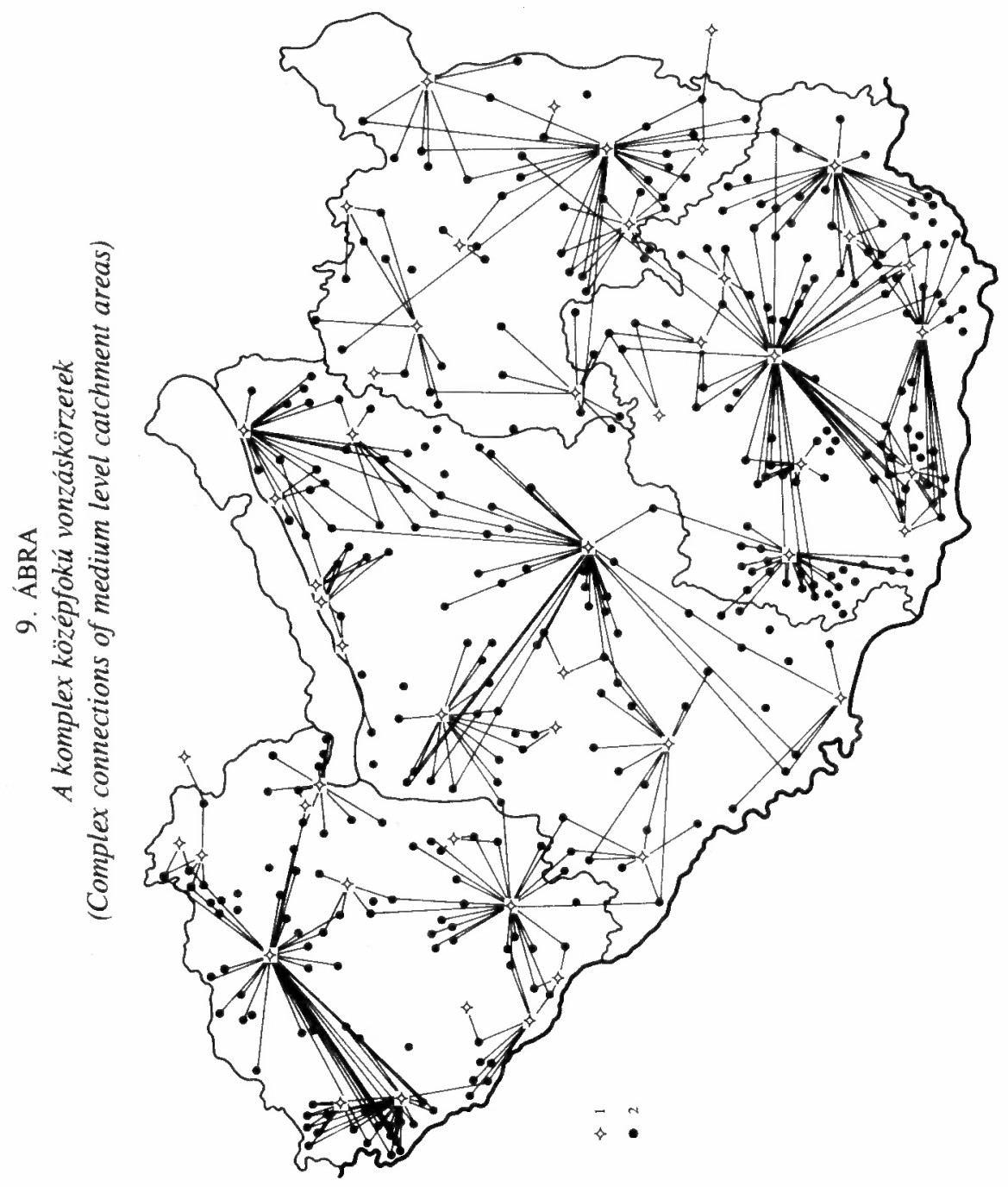




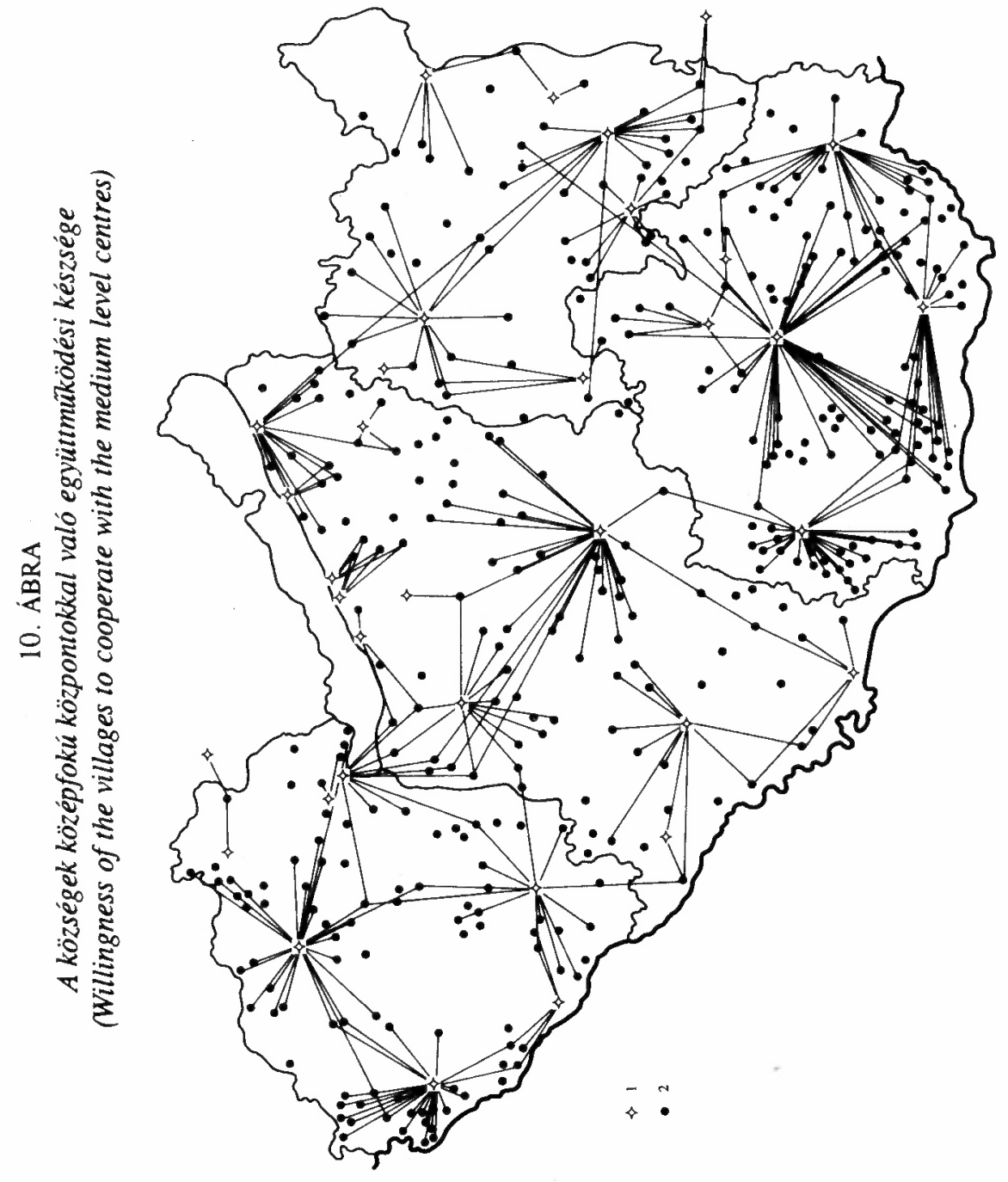


A régióközi vonzáskörzeti kapcsolatok, s jövôbeni együttmũködési törekvések nem széles körüek. Sümegcsehi szinte minden tekintetben Sümeghez vonzódik, s csak kiegészítố jellegũ kapcsolatokat épített ki Zalaszentgróttal. Bátaszék, Pörböly egyaránt Baja és Szekszárd között , ,ingadozik", de méginkább összekötô kapcsolatokat formál.

A megyehatár menti ,átvonzódások" és komplex együttmüködési törekvések már szélesebb körũek mint a régióköziek, ezek az átfedések megjelennek minden szomszédos megyehatáron. A kapcsolatok intenzitása elsốsorban a megyehatáron vagy annak közelében elhelyezkedô város nagyságától függ. Gyékényes nagykanizsai kapcsolódása rendkívül erôs, s e mellett kiegészítố tartalmú a Csurgóval és Nagyatáddal fenntartott kapcsolatrendszere. Keszthely hatása erôs Somogy megye északnyugati részén, s az idegenforgalomban és a környezetvédelemben érdekelt somogyi települések szívesen alakítanának ki vele szélesebb körũ együttmüködést.

A megyén belüli vonzáskörzetek elkülönülése sem mechanikus. Nagykanizsa és Zalaegerszeg között egy viszonylag széles közös vonzáskörzeti sáv alakult ki, hasonlóan zonális jellegũ a Zalaegerszeg - Lenti vonzáskörzet elhatárolódása is.

A Balaton-térség belsô vonzáskörzet-szervezôdése rendkívül sajátos, egyes részeken problematikus. A déli part városainak vonzáskörzetei nem válnak el élesen. A Keszthely töl Siófokig szinte teljesen beépült partszakasz sokközpontú településközi kapcsolatrendszert hoz létre.

\section{Összegzés}

A kérdõív feldolgozásának tapasztalatai azt mutatják, hogy a módszer alkalmas a településközi kapcsolatok sokszínưségének, belsổ tartalmának és területi konfigurációjának feltárására.

A Dél-Dunántúl középfokú központ- és vonzáskörzet-rendszere jelentôs részben történetileg determinált. A közös jegyeken túl - részben a megyeszékhelyek eltérô fejlettsége következtében - megyénként is sajátos struktúrák alakultak ki. A középfokú vonzáskörzetek nem képeznek zárt területi formációt, mindenekelổtt a régió, a megye- és a vonzáskörzeti határon fekvố települések vonzódása többirányú.

A községek jelentôs részében megérett a felismerés, hogy ,önállóságuk megélése után', érdekeiket felismervé és érvényesítve ismét szerves együttműködést alakítsanak ki a korábbi vagy új térségi központtal. Ez az együttmüködés az érdekközösség felismerésén nyugodhat, kívülrôl erôltetni nem kell és nem szabad, de befolyásolni lehet, mindenekelốtt a társulások fokozottabb anyagi támogatásával. 


\section{THE TERRITORIAL ORDER OF THE MEDIUM-LEVEL CATCHMENT AREAS OF SOUTH TRANSDANUBIA}

\section{ZOLTÁN HAJDÚ}

From 876 settlement self governments of South Transdanubia (Baranya, Somogy, Tolna, Zala) $378(43.2 \%)$ filled out the questionnaire about the inner catchment area organisation of the region.

The questionnaire and the answers given included the evaluation of the administrative, educational, trade, financial, personal service, heath care, productive connections, the definition of the centres of the catchment areas.

In South Transdanubia is is usually the towns that have functions of seat administration of medium-level catchment areas - though not in totality - , the medium-level catchment areas are historically determined many times.

The medium-level catchment areas do not form closed spatial units, most of the catchment areas have so-called "perforated" space. It is especially the bigger, functionally more developed county seats whose attraction reaches into the catchment areas of other towns.

The medium-level catchment areas reach over the borders of both the county and the "region". 
Tér és Társadalom 8. évf. 1994/1-2. 24. p.

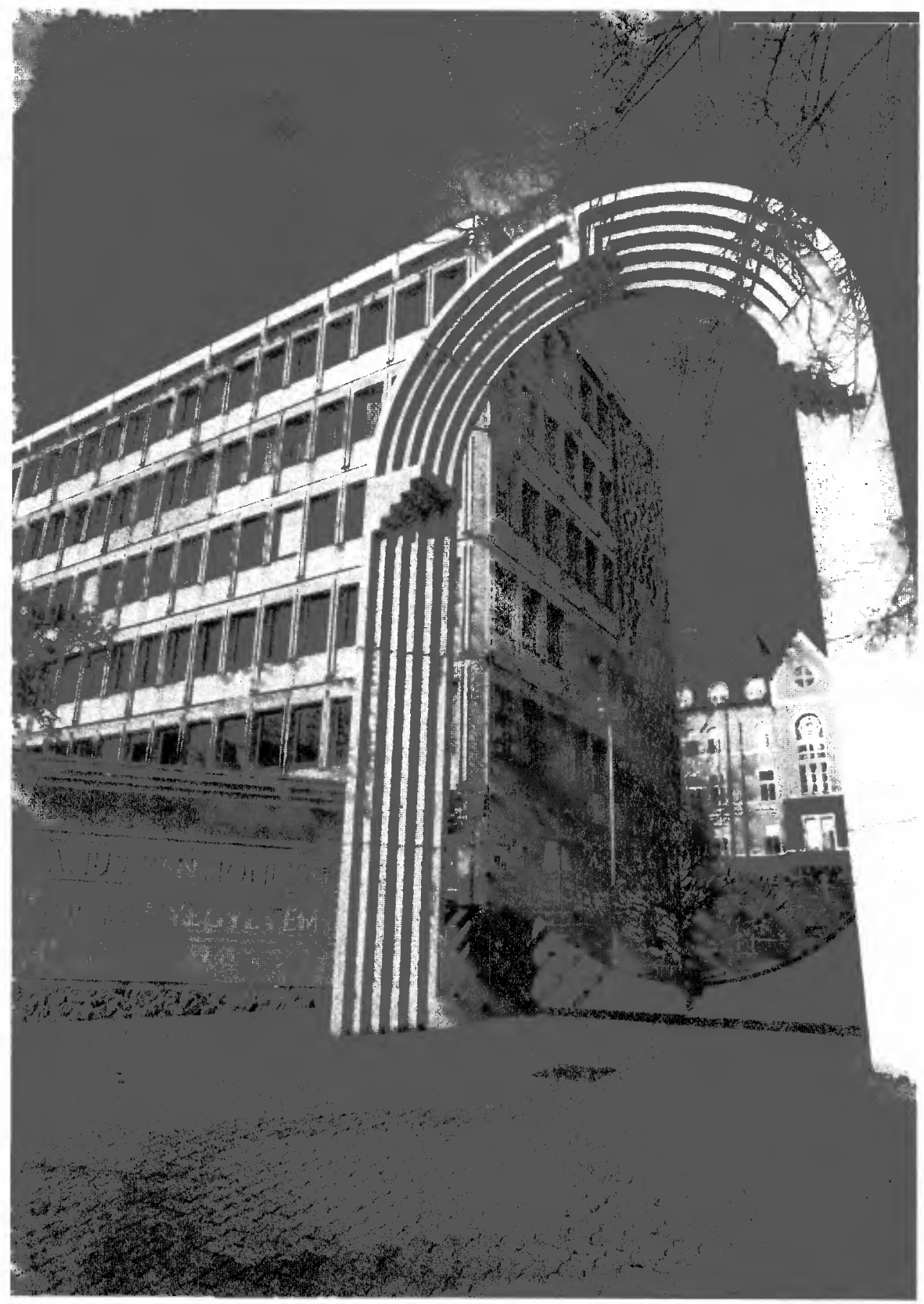

Janus Pannonius Tudományegyetem (Mánfai Gy.) 